During the year 1887 , Osler's anemometer showed an excess of about 17 revolutions of the vane in the positive direction N., E., S., W., N., excluding the turnings which are evidently accidental.

The number of hours of bright sunshine recorded during 1887 by Campbell's sunshine instrument (Prof. Stokes's improved pattern) was I4OI, which is about I90 hours above the average of the preceding ten years. The aggregate number of hours during which the sun was above the horizon was 4454 , so that the mean proportion of sunshine for the year was 0.315, constant sunshine being represented by $\mathrm{I}$.

The rainfall in 1887 was $19^{\circ} 9$ inches, being $4^{\circ} 8$ inches below the average of the preceding forty-six years.

There has been no failure in the automatic drop of the Greenwich time-ball, but on four days the ball was not raised on account of the violence of the wind.

The automatic drop of the Deal time-ball failed on six days owing to interruption of the telegraphic connections, and on two days high wind prevented the raising of the ball. There has been no case of failure of the I $\mathrm{p} \mathrm{m}$. signal to the Post Office Telegraphs.

There have been twenty-three failures in the automatic signals from the Westminster clock since the date of the last report. The error of the clock was insensible on 25 per cent. of the days of observation, Is. on 38 per cent. $2 \mathrm{~s}$. on 20 per cent, $3 \mathrm{~s}$. on 15 per cent., and $4 \mathrm{~s}$. on 2 per cent.

Provision has been made in the estimates for the expense of a re-determination of the difference of longitude between Greenwich and Paris, and correspondence has been carried on with the French authorities on the subject. The regretted death of General Perrier occurred before any definite plan had been settled; but his successor, M. le Commandant Bassot, has taken the matter up warmly in concert with Admiral Mouchez, and the French Bureau des Longitudes has approved the scheme, which is to include a determination of the longitude of Dunkirk. Three French delegates (M. Lœwy, M. Bassot, and M. Defforges) propose to visit Greenwich very shortly to settle the details of the plan of operations which it is intended to carry out in the autumn. In preparation for the work, Mr. Turner and Mr. Lewis have observed for practice, by eye and ear, a number of galvanometer signals sent by another observer and automatically registered on a chronograph, five sets of ten signals having been recorded on each of seven days.

The Report concludes as follows :-

In my last Report it was suggested that the instrumental equipment of the Observatory should be supplemented by a photographic refractor of 13 inches aperture (equatorially mounted) to enable Greenwich, as the National Observatory, to take its share in the scheme for forming a photographic map of the heavens, and for thus extending our knowledge of the places of the fixed stars. Consequent on the resolution of the Board of Visitors at the last visitation, I brought this question of the insufficiency of our instruments for the present wants of astronomy to the notice of the Admiralty and of the Chancellor of the Exchequer, and the matter is still under the consideration of the Government. If the Royal Observatory is to take part in this work of carrying out one of the principal objects for which the Astronomer-Royal was appointed, it appears to be essential that a decision should be arrived at without delay, in view of the circumstance that thirteen Observatories (including those of Melbourne and Sydney in our own colonies) have already ordered their instruments, which are to be completed by the end of the present year.

Allusion was made in the last Report to the increased demands made on the Observatory in recent years both by the scientific and the general public, and in view of the consequent development of work it now becomes necessary to review the position of the establishment, which was constituted many years ago, when the conditions were very different. In order to understand the difficulty of the present situation it is necessary to bear in mind the following facts:-In 1835 there were five assistants (excluding the chief assistant), having no computers to superin- tend, no extraneous work beyond the care of a relatively small number of chronometers for the Navy, no magnetic and meteorological observations, no altazimuth observations, no spectroscopic and photographic observations. At the present time there are eight assistants (excluding the chief assistant) having fifteen computers to superintend, and of this staff two assistants are absorbed by the magnetic and meteorological branch, one by the altazimuth, and two by the spectroscopic and photographic branch, leaving only three assistants to do the astronomical work, which in 1835 required five assistants, and in addition to perform all the extraneous duties which the Astronomer-Royal has felt it desirable to undertake in the public interest.

Under these circumstances it becomes a matter for serious c snsideration whether, unless adequate provision be made for the primary objects of the Observatory, extraneous work, such as the supply of time-signals, may not have to be dropped. The service of hourly time signals throws considerable work on myself and the staff of the Observatory, and, as it is purely voluntary, it appears to me that a condition of its maintenance must be that arrangements shall be made to enable the proper work of the Observatory to be carried on and suitably developed.

\section{INDUSTRIAL TRAINING.}

$A \mathrm{~T}$ a meeting held at the Mansion House on Friday last, in support of the scheme for establishing Polytechnic Institutes in South London, an able and interesting speech was delivered by Lord Salisbury. Having pointed out that of late years much had been done for primary education, he went on to show that a sound system of secondary education for the great mass of the people was not less necessary. Secondary education, as we know it at present, had been established for the benefit of classes who in the main had not to work for their living. Plainly, therefore, it was not adapted to the needs of the working classes. "What we have now to do," he continued, "is to provide an education which will develop for each man the faculties that Nature has given him in such a manner that he may be as active, profitable, and prosperous a member of the community as possible." Lord Salisbury then passed in review the efforts which have been made in London to meet the demand for technical instruction, and concluded as follows :-

"I have only one more word to say, just to call your attention to another aspect of this case and to commend it to your efforts. We live in a time when men multiply fast, but apparently the means of supporting them do not multiply as rapidly ; when there is vehement competition and occasionally intervals of deep depression. And if you should look more closely, you will find that one cause at least of this phenomenon is that man, as the mere owner of muscle, is being edged out by another and more powerful competitor. Merely as an agent of physical force, as the possessor of the power of labour, the steamengine is a competitor which drives him easily out of the market. And more and more the mere unskilled labour is being made unnecessary by the development of the forces which mechanical science has discovered. And as the world goes on, you must expect this tendency to increase. You must expect mechanical force to become more varied and more powerful and more cheap, and the competition with human arms and limbs to become more hopeless. But there is one region where the machine can never follow the human being, and that is in the exercise of thought. In skill, in cultivated mind, in the power to adapt the processes of thought to the laws of Nature, in all that we call 'skilled labour' of the highest kind, in that man must always have a monopoly, and need fear no encroachment from the competition of the steam-engine. It is to the development of his powers in that respect that the increase in the means of subsistence and the opening of new paths of self-support must be found. On all of us, in whatever position we are, is pressing, as one of the most anxious subjects of public care, the discovery of methods 
by which the teeming millions of this country shall be able to maintain themselves in a prosperous, decent, and comfortable condition. We cannot find in their unskilled labour a satisfaction of that want. The difficulties are enhanced by the fact that our neighbours in other countries have been sensible of the superiority which skilled education can confer, and have not been slow to take advantage of it. If we will not be left behind in the race, if we desire to find any satisfactory solution for the deepest and the most inscrutable problem of our time, if we wish our complex community and high civilization to be maintained secure from all the dangers which the presence of unfed, unprosperous, untaught millions must bring upon them, we shall do our utmost to give a healthy and a rapid development to the secondary education of the working classes."

The Times, commenting on the meeting addressed by Lord Salisbury, says:-

"The Prime Minister spoke of the occasion as marking an era in the development of secondary education. The expression is scarcely too emphatic. Many of those present at the Mansion House have been for years labouring for that cause, and often with little confidence that they would ever see the produce of the seed which they sowed. Now, however, the husbandman's hopes rise, for he discerns everywhere lusty shoots flourishing, and he knows that a harvest is at hand. It is no small matter to find Government recognition of the importance of manual or technical education in a Bill which will enable any School Board to promote it. What London has done other cities will do, and here much has been done, and still more is imminent. The Polytechnic and the Beaumont Institutes are admirable pioneers. The projected Institutes for South London will soon, we should hope, be established; and the Charity Commissioners have promised to grant $\$ 50,000$ in aid of an Institute for the south-west parishes north of the river on condition that the same amount is contributed by the district. What limits are there to the possible benefits from a network of such institutions over London and other great cities? Even if they fail to sharpen the wits of our workers, and to prepare them for their part in that struggle which tb? Prime Minister eloquently described as the course of civilization, if the foreign clerk continues to oust our own youth, we may count with certainty on deep and farextending good from institutions mingling instruction with recreation, uniting many of the good points of clubs and schools, serving to some as ladders for ambition to climb with, to others as refuges from the public-house, and introducing intellectual light into the dark places of our cities. For many a man and woman, especially at the outset of life, narrow means would lose all terror if there were open of an evening an Institute such as was described yesterday; and it would be the best palliative of that dull monotony which in some walks of life is more injurious, as it is immensely more common, than downright viciousness."

For many a day, as our readers know, we have been urging the necessity for the establishment of a proper system of technical instruction. The subject is one of such pressing importance that we have returned to it again and again, seeking to present it in many different aspects ; and Lord Salisbury's speech and the article in the Times may be taken as indications that large classes of the community have at last begun to understand that the nation has no time to lose in setting about a task which ought long ago to have been most seriously undertaken. Even if the question had little direct relation with economic interests, it would be for many reasons desirable to secure for manual training a place among our educational methods. Attention has hitherto been too exclusively devoted in schools to such knowledge as may be derived from books. It is necessary, from the strictly educational point of view, that teachers should aim at a wider, more direct, and more practical development of the mental powers of their scholars. But other and even more fundamental interests are also concerned. The leading nations of the world, our rivals in industry and trade, have already perceived the benefits to be secured from a thorough mastery, on the part both of employers and employed, of the principles of science as applied to agricultural and manufacturing processes. The result is that in many of the best markets, where our supremacy as a trading people was formerly unquestioned, we find ourselves at a disadvantage; and it is certain that unless we place ourselves on a level with our competitors we shall have to pass through some very bitter national experiences. The question is really one of life and death for England. It is a question whether in the near future there are or are not to be sufficient employment and remuneration for the vast and growing masses of her population.

\section{WEISMANN ON HEREDITY.}

THE fundamental property of all living matter is assimilation and consequent growth; and reproduction is merely discontinuous growth. This is most apparent in the Protozoa, where the primitive form of reproduction-division into two parts -is common. Each part exactly resembles the other part, and both the parent. Heredity in them merely means identity of bodily substance, and consequent identity of vital phenomena. In Metazoa there is a sharp distinction between reproductive cells and body cells. In many cases it is certain that the reproductive cells of each new organism arise directly from the reproductive cells of the parent. Here there is as manifestly a continuity or identity of the germplasma as in the Protozoa. As has already been explained by Prof. Moseley in this paper, Weismann extends this phylogenetic continuity of germ-cell, or at least of germplasma-the essential constituent of the germ-cell-to all the Metazoa.

In the Metazoa, the germ-cells, instead of remaining single, give rise to the vast number of somatic cells which compose the adult structure. The form, arrangement, and succession of these depend on the germ-plasma; and as there is continuity of this from generation to generation it follows that the structures derived from it are identical in each generation. Obviously this view excludes the possibility of the inheritance of acquired characters. But this inheritance has been proved neither by observation nor by experiment, and it has been impossible to conceive any satisfactory mechanism by which it could be accomplished.

Weismann believes that the theory of the inheritance of acquired characters is not required to explain the phenomena of the organic world. In the production of an acquired character two forces are at play, and these forces in relation to the organism may well be called centripetal and centrifugal. The centrifugal forces are ultimately referable to the molecular constitution of the germ-plasma, and are transmitted with the other properties of the germ-plasma from generation to generation. Changes in the centrifugal forces due to that mixing of plasmata which is the object of amphigonic reproduction constantly occur. Adaptation and differentiation result from the action of the environment (centripetal forces) on these continualchanges in the possibilities of the organism. Not acquired characters, but the internal possibjlities of them, are transmitted : not the results, but the centrifugal causes of them, are transmitted and accumulated by natural selection. An example will make this clear. Giraffes are certainly descended from short-necked forms. According to the old theory, during life their ancestors, by constantly stretching to reach higher and higher branches of the aracias, \&c., on which they fed, elongated their necks a

\footnotetext{
I "Ueber die Vererbung," von Dr. August Weismann. (Jena, 1884.)
} 